\title{
Efektivitas Penerapan Metode Hypnoteaching terhadap Motivasi Belajar Matematika Siswa SMP
}

\author{
Arga Dinasty $^{1}$, I Putu Pasek Surya wan ${ }^{2 *}$, I Made Sugiarta ${ }^{3}$ \\ 1,2,3 Universitas Pendidikan Ganesha \\ putu.pasek@undiksha.ac.id
}

\begin{tabular}{|l|l|l|l|} 
Received: 07-03-2021 & Revised: 14-05-2021 & Accepted: 23-05-2021 & Published: 06-06-2021 \\
\hline
\end{tabular}

\begin{abstract}
ABSTRAK
Penelitian ini memiliki tujuan untuk mengetahui pengaruh metode hypnoteaching terhadap motivasi belajar matematika siswa kelas VIII SMP Negeri 1 Muncar. Penelitian ini termasuk jenis penelitian eksperiemen semu (quasi experiment) dengan rancangan post test only control grup. Populasinya adalah siswa kelas VIII SMP Negeri 1 Muncar tahun ajaran 2020/2021 yang berjumlah 274 orang. Penentuan sampel dilakukan dengan cara teknik cluster random sampling yang disyaratkan terpenuhinya kesetaraan populasi menggunakan uji ANAVA satu jalur. Data penelitian adalah motivasi belajar matematika siswa yang diperoleh melalui penyebaran instrumen di akhir penelitian. Data dianalisis menggunakan uji Liliefors, uji Levene dan uji $t$ satu ekor dengan taraf signifikasi $5 \%$. Hasil analisis menunjukkan nilai $t_{\text {hitung }}=3,032>t_{\text {tabel }}=1,996$ sehingga tolak $\mathrm{H}_{0}$ dan $\mathrm{H}_{1}$ diterima. Hasil analisis menjelaskan bahwa motivasi belajar matematika siswa yang mengikuti pembelajaran metode hypnoteaching lebih tinggi daripada motivasi belajar matematika siswa kelompok yang mengikuti pembelajaran konvensional. Disimpulkan bahwa metode hypnoteaching berpengaruh positif terhadap motivasi belajar matematika siswa kelas VIII SMP Negeri 1 Muncar.
\end{abstract}

Kata Kunci : Efektivitas, Metode Hypnoteaching, Motivasi Belajar Matematika

\section{ABSTRACT}

This research aimed to find out the influence of hypnoteaching method toward the student' motivation in learning mathematics in the eight grade students of SMP Negeri 1 Muncar. This research was a quasi-experiment research with post-test only controls group design. The population were 274 eigth grade students of SMP Negeri 1 Muncar in the academic year 2020/2021. The sample was taken by using of cluster random sampling technique that was required the fulfillment of population equality by using one-way ANOVA test. The data collection was done by conducting an instrument in the end of research. The data were analyzed by using Liliefors test, Levene test and a single $t$-tail test with a signification level $5 \%$. The result showed the value $t_{\text {count }}=$ 3,032 > $t_{\text {table }}=1,996$ which mean $H_{0}$ was rejected and $H_{1}$ was accepted. This research showed that the students' motivation that was treated by hypnoteaching method was higher than the students' motivation which was treared by conventional method in learning mathematics. It can be concluded that hypnoteaching method gave positive effect for students' motivation in learning mathematics for the eight grade student of SMP Negeri 1 Muncar.

Keywords: Effectiveness, Method Hypnoteaching Method, Learning Motivation Mathematic

\section{PENDAHULUAN}

Pendidikan memiliki pengaruh dalam perubahan kehidupan individu. Pendidikan dikatakan sebagai tombak penting dalam kehidupan mengenai nilai sikap, pengetahuan dan keterampilan setiap individu (Parwati, Suryawan, \& Apsari, 2018). Mengherankan dalam 
pendidikan seandainya tidak ada evaluasi secara berkala khususnya pada sistem pembelajaran. Terdapat kegiatan mengajar dan belajar dalam pembelajaran yang perlu perhatian termasuk pada pembelajaran matematika (Suwarman et al., 2018).

Matematika pada hakikatnya memiliki peran dalam mengembangkan nalar siswa menyelesaikan permasalahan dengan berpikir secara logis, kritis maupun terstruktur (Dewi, 2018). Erat kaitannya permasalahan pada proses pembelajaran maupun kehidupan sehari-hari menjadikan matematika berpengaruh penting dalam perkembangan IPTEK (Septian, Darhim, \& Prabawanto, 2020a). Pandangan siswa di Indonesia hingga sekarang terkait matematika lebih mengarah ke sesuatu negatif seperti pelajaran yang sulit, serba angka, rumus maupun memusingkan. Anggapan siswa tersebut dikarenakan matematika memiliki objek yang bersifat abstrak dilengkapi dengan banyaknya rumus (Utami \& Cahyono, 2020).

Pandangan negatif yang mucul semakin diperkuat dengan potret lapangan yang memperlihatkan adanya faktor lain dimana siswa yang merasa dirinya ingin mencapai suatu pembelajaran yang bermakna dengan bersungguh - sungguh aktif dalam kegiatan belajar mengajar menjadikan siswa lainnya merasa enggan untuk bertanya karena kurang percaya diri dengan kemampuannya atau menunggu penyelesaian yang ada sehingga berakhir dengan munculnya semangat dan ketertarikan siswa dalam matematika yang kecil bahkan tidak ada sama sekali (Inayah, Septian, \& Suwarman, 2020). Gambaran tersebut mengungkapkan bahwa siswa yang cenderung rajin belajar dengan senang hati akan mengulang kembali pelajaran yang didapatkan yang berdampak munculnya kesukaan terhadap matematika dan membuatnya tidak mengalami kesulitan dalam pembelajaran (Hasibuan, 2018).

Selain itu, bertitik tolak pada hasil survei Programme for International Student Assesment tahun 2018 yang menyatakan skor rata-rata Indonesia untuk mata pelajaran matematika yaitu 379 dengan peringkat ke 73 dari 79 negara. Terlihat lebih rendah jika dibandingkan dengan hasil PISA tahun 2015 yang sebesar 386 dengan peringkat 63 dari 69 negara (Hewi \& Shaleh, 2020). Pola pikir demikian yang menyebabkan Indonesia perlu inovasi pembelajaran agar pandangan yang tumbuh bersifat positif khususnya mata pelajaran matematika (Budiman \& Rosmiati, 2020; Septian, Darhim, \& Prabawanto, 2020b).

Work From Home merupakan langkah yang dilakukan pemerintah sejak tahun 2020 dikarenakan adanya penyebaran virus corona dengan kebijakan setiap kegiatan dilakukan dirumah masing- masing termasuk pembelajaran. Pembelajaran matematika dalam keadaan 
penyebaran virus corona memerlukan perhatian khusus. Terbitnya Surat Edaran Mendikbud Nomor 4 Tahun 2020 tentang pelaksanaan kebijakan pendidikan dalam masa darurat penyebaran Coronavirus Disease (COVID-19) yang memperkuat pembelajaran dilakukan secara jarak jauh melalui media online yang mendukung. Beberapa hal yang dialami siswa dalam pembelajaran online seperti inisiatif siswa untuk belajar mandiri sesuai kebutuhannya selain materi yang sudah disediakan oleh guru masih belum tumbuh, cara mengatur pembelajaran terkesan belajar seperlunya, maupun kesulitan dan kesalahan yang dihadapi siswa membuat menyerah tanpa adanya niatan untuk mendalami materi tersebut (Utami \& Cahyono, 2020).

Mengalami burnout akibat Work From Home dalam jangka waktu lama dapat dirasakan oleh siswa dan berdampak pada perilakunya. Mudahnya merasakan kebosanan, kejenuhan maupun kemalasan dalam melakukan kegiatan belajar mengajar berdampak pada mengecil semangat yang timbul dikarenakan pembelajaran yang monoton dan tidak ada inovasi (Trisnawati, 2020). Burnout dalam kondisi ini bisa saja terjadi dikarenakan pembelajaran hanya berlangsung dari rumah. Kendala terkait budaya pembelajaran yang belum pernah diterapkan, mempengaruhi daya serap siswa dikarenakan kebiasaan siswa yang berinteraksi secara langsung dan berdampak kepada semangat belajar yang semakin menurun (Purwanto et al., 2020). Penerapan pembelajaran secara online yang terkesan mendadak dan perlu upaya adaptasi dari siswa terlebih guru. Upaya beradaptasi dengan mengandalkan kreativitas dari guru seperti pembuatan konten pembelajaran, menyusun rencana pelaksanaan pembelajaran (RPP), atau pemilihan model maupun metode yang tepat sesuai dengan pembelajaran inovatif adalah suatu kebutuhan mengingat motivasi siswa perlu ditumbuhkan pada keadaan ini.

Tumbuhnya motivasi dipicu dari luar maupun dalam diri siswa sesuai dengan tujuan yang dicapai. Demikian Mc. Donald (Sadirman, 2011) mengatakan motivasi sebagai energi dalam diri seseorang yang muncul didahului tanggapan berupa tujuan. Motivasi siswa menjadi penting karena akan merubah aktivitas belajar dan pandangan negatif terkait mata pelajaran matematika. Motivasi dapat berpengaruh terhadap arah perilaku seseorang melalui kebutuhan dan keinginannya (Parwati et al., 2018). Melihat motivasi perlu ditumbuhkan, tentunya pembelajaran yang kreatif dan inovatif perlu diterapkan dengan model atau metode yang sesuai. Dalam hal ini yaitu metode hypnoteaching. Karakteristik dari metode yang digunakan menunjukkan keselaraasan antara situasi dan kondisi khusus yang dihadapi oleh guru dalam pembelajaran (Parwati et al., 2018). 
Hypnoteaching dimaknai dari hypnosis yang berarti sugesti dan teaching berarti mengajar (Yustisia, 2012). Metode yang menyampaikan materi dengan memanfaatkan fungsi pikiran bawah sadar siswa melalui sugesti. Hypnoteaching adalah suatu metode yang disampaika dengan teknik komunikasi persuasif maupun sugesti dalam pembelajaran (HM Anwar, 2017). Metode ini secara tidak langsung memberikan kesan terhadap pembelajaran menyenangkan melalui komunikasi secara persuasif dengan menekankan pikiran bawah sadar siswa.

Langkah metode hypnoteaching antara lain niat dan motivasi, 2) pacing atau menyamakan posisi, 3) leading berartu mengarahkan sesuatu, 4) penggunaan kata-kata positif, 5) pujian dan, 6) modeling atau pemberian teladan (HM Anwar, 2017). Keberhasilannya tidak terlepas dari niat dan motivasi diri sendiri diiringi penyamaan gerak tubuh, gaya bahasa, serta gelombang otak yang menyebabkan rasa nyaman dan berpengaruh terhadap aktivitas siswa mengikuti arahan dari guru (Kusuma, 2019). Didukung pula penggunaan kata-kata positif yang dapat memperngaruhi psikis siswa sehingga siap menerima materi yang di berikan (Miftakhurozaq, 2018). Penerapan pada pembelajaran matematika memberikan ketertarikan bagi siswa sehingga timbul motivasi dan pengaruh positif untuk terus berkembang melakukan kegiatan berkaitan matematika.

Penelitian sebelumnya telah memaparkan terkait metode hypnoteaching seperti yang dilakukan Safitri dan Purnamasari (2017) dengan hasil keefektifan pembelajaran hypnoteaching lebih terlihat dari pada pembelajaran secara konvensional. Penelitian Kasmaja (2016) angkat bicara terkait hasil pembelajaran metode hypnoteaching efektif mengembangkan motivasi belajar siswa dengan diikuti meningkatnya hasil belajar matematika dalam pokok bahasan bangun datar segiempat. Tapi belum banyak yang meneliti penelitian ini dengan dasar kekhawatiran akan munculnya rasa burnout pada diri siswa karena terlalu lama Work Form Home, sehingga meyakinkan peneliti terkait penggunaan metode hypnoteaching sebagai nilai tambah untuk beberapa ketertarikan pada pembelajaran seperti menyediakan video animasi 2D yang dikemas semenarik mungkin dengan permasalahan matematika, maupun video melakukan senam otak yang diberikan sebelum pembelajaran dimulai untuk mendukung pelaksanaan tahap pacing dan menjadikan lebih inovatif dan kreatif di pembelajaran yang dilakukan secara online.

Sebelum Safitri dan Purnamasari (2017) dan Kasmaja (2016), telah dilakukan penelitian yang berkesimpulan bahwa pembelajaran terkait metode hypnoteaching memiliki peningakatan motivasi belajar mahasiswa (Hasbullah \& Rahmawati, 2015). 
Terdapat penelitian lainnya seperti yang dilakukan Diantari dkk (2014) dengan memadukan antara pembelajaran hypnoteaching dan model pembelajaran problem based learning. Terdapat perbedaan hasil belajar siswa yang mengikuti pembelajaran model problem based learning berbasis hypnoteaching dengan model pembelajaran konvensional. Belum lama ini pembelajaran hypnoteaching dipadukan dengan pendekatan contextual teaching and learning yang didapatkan ada pengaruh terhadap kemampuan komunikasi matematis siswa (Qomario, 2018). Beberapa penelitian yang telah dilakukan memberikan gambaran bahwa metode hypnoteaching memberikan dampak positif terkait hasil belajar khususnya pada motivasi belajar matematika siswa.

Bedasarkan pemaparan tersebut, ketertarikan memperoleh bukti terkait pengaruh metode hypnoteaching terhadap motivasi belajar matematika siswa kelas VIII SMP Negeri 1 Muncar. Tujuannya untuk mengetahui apakah motivasi belajar matematika siswa dengan metode hypnoteaching lebih tinggi daripada motivasi belajar matematika siswa dengan metode pembelajaran konvensional.

\section{METODE PENELITIAN}

Penelitian ini merupakan jenis penelitian eksperimen semu (quasi eksperiment) dengan desain post test only grup design. Penelitian jenis ini ditegaskan bahwa untuk unit terkecil berupa individu atau seseorang penempatannya tidak dilakukan secara acak ke dalam kelompok eksperimen maupun kontrol (Hastjarjo, 2019).

Populasi penelitian ini adalah siswa kelas VIII SMP Negeri 1 Muncar pada tahun pelajaran 2020/2021 sebanyak 274 siswa. Ukuran sampel penelitian 69 diperoleh kelas VIII A sebanyak 36 siswa sebagai kelompok eksperimen dan VIII B sebanyak 33 siswa sebagai kelompok kontrol. Perlakuan dilakukan dengan memberikan metode yang berbeda dilengkapi LKS dan video pembelajaran terkait materi pola bilangan kelas VIII semester 1 melalui platform schoology. Variabel dalam penelitian ini, variabel bebas berupa metode hypnoteaching dan variabel terikatnya berupa motivasi belajar siswa.

Dalam penelitian ini memerlukan data skor motivasi belajar matematika siswa dengan instrumen penelitian yaitu non tes berupa angket motivasi belajar matematika siswa yang diadaptasi dari Mertasari (2003) menggunakan skala likert. Validasi instrumen dilakukan oleh dosen ahli dari prodi pendidikan matematika Universitas Pendidikan Ganesha (Undiksha) Singaraja. Uji validitas dan reabilitas telah dilakukan yang menyatakan instrumen telah valid dan reliable untuk digunakan dalam penelitian. Terdapat 20 butir instrumen motivasi belajar matematika siswa dan tes diberikan di akhir pertemuan 
(post-test) . Analisis data penelitian ini menggunakan uji t satu ekor yang disyaratkan uji normalitas dengan uji Liliefors yang didapatkan bahwa data motivasi belajar siswa bersifat normal dan uji homogenitas dengan uji Levene yang didapatkan bahwa data motivasi belajar siswa bersifat homogen.

\section{HASIL DAN PEMBAHASAN}

Sebelum penentuan sample menggunakan cluster random sampling, penyetaraan populasi dilakukan dengan uji ANAVA satu jalur untuk mengetahui apakah terdapat perbedaan kemampuan atau tidak antara siswa dengan kemampuan tinggi, sedang maupun rendah pada masing-masing kelas. Diperoleh nilai $\mathrm{F}$ hitung sebesar 1.403 dengan $\mathrm{F}$ tabel sebesar 1.98 yang menandakan nilai $\mathrm{F}$ hitung $<\mathrm{F}$ tabel dan $\mathrm{H}_{0}$ diterima. Hal tersebut menyatakan terdapat kesetaraan populasi. Diperoleh dua kelompok dengan salah satu kelompok menerima pembelajaran dengan metode hypnoteaching dan yang lainnya menggunakan metode konvensional. Hasil analisis data penelitian berupa skor motivasi belajar matematika siswa diperoleh dari kegiatan post-test dengan menyebar angket sebagai berikut.

Tabel 1. Hasil Rata-Rata

\begin{tabular}{ccc}
\hline \multirow{2}{*}{ Variabel } & \multicolumn{2}{c}{ Kelompok } \\
\cline { 2 - 3 } & Eksperimen & Kontrol \\
\hline $\mathrm{N}$ & 36 & 33 \\
\hline $\bar{X}$ & 74.94 & 69.58 \\
\hline $\mathrm{SD}$ & 7.753 & 6.874 \\
\hline
\end{tabular}

Pada Tabel 1 rata-rata skor motivasi belajar siswa kelompok eksperimen lebih tinggi daripada kelompok kontrol yang menggunakan metode konvensional. Jika dipandang dari standar deviasi terhadap rata-ratanya menjelaskan skor motivasi belajar matematika siswa menyebar pada kelompok eksperimen daripada kelompok kontrol. Gambar 1 terkait perbandingan hasil rata - rata skor rmotivasi kelas eksperimen dan kelas kontrol. 


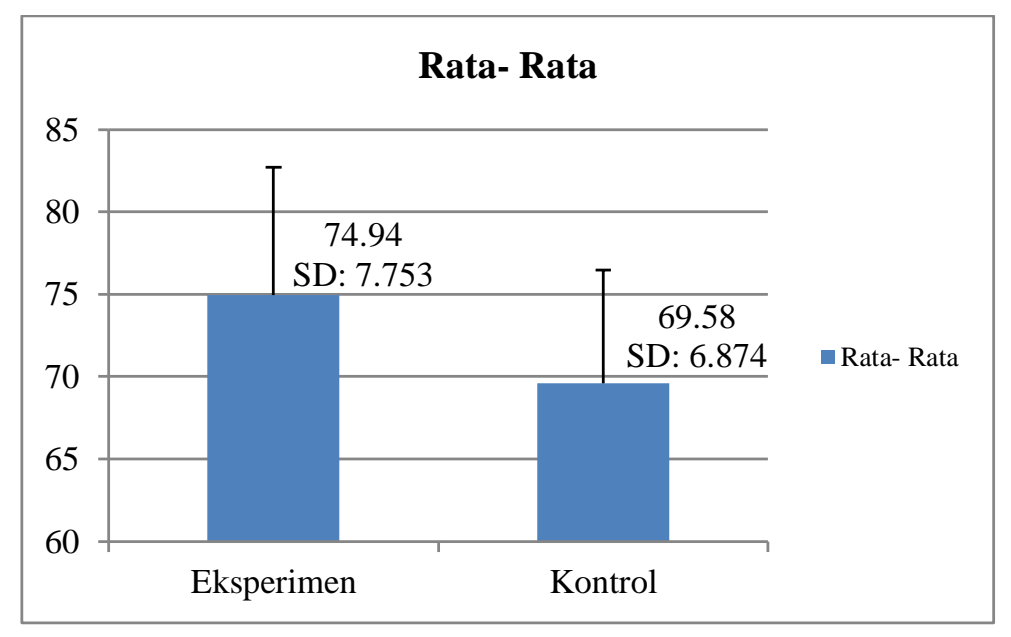

Gambar 1. Diagram Batang Hasil Rata-Rata

Selanjutnya melakukan uji prasyarat yaitu uji normalitas dengan hasil disajikan pada Tabel 2 dan uji homogenitas pada Tabel 3.

Tabel 2. Hasil Data Normalitas dengan Uji Liliefors

\begin{tabular}{cccc}
\hline Kelompok Sampel & Lhitung & Ltabel & Kesimpulan \\
\hline Eksperimen & 0,105 & 0.148 & Normal \\
\hline Kontrol & 0,07 & 0.154 & Normal \\
\hline
\end{tabular}

Berpedoman pada Tabel 2 bahwa nilai $\mathrm{L}_{\text {hit }}<\mathrm{L}_{\text {table }}$. Dengan demikian kedua kelompok memiliki sebaran data berdistribusi normal.

Tabel 3. Hasil Uji Homogenitas Varians dengan Uji Levene

\begin{tabular}{|c|c|c|}
\hline \multirow{2}{*}{ Kelompok } & \multicolumn{2}{|c|}{ Data Motivasi Belajar Matematika Siswa } \\
\hline & Eksperimen & Kontrol \\
\hline $\mathrm{N}$ & 36 & 33 \\
\hline $\mathrm{W}$ & \multicolumn{2}{|c|}{0,619} \\
\hline F tabel & \multicolumn{2}{|c|}{3,984} \\
\hline Kesimpulan & \multicolumn{2}{|c|}{ Homogen } \\
\hline
\end{tabular}

Tabel 3 mengidentifikasikan bahwa nilai $\mathrm{W}<\mathrm{F}_{\text {tabel }}$ yang menyatakan tidak ada perbedaan varians antara kelompok eksperimen dan kelompok kontrol (data homogen). Data motivasi belajar matematika siswa sudah memenuhi asusmsi dari uji prasyarat sehingga pengujian hipotesis dapat dilanjutkan dengan hasil sebagai berikut.

Tabel 4. Hasil Uji Hipotesis dengan Uji t satu ekor

\begin{tabular}{cccc}
\hline Kelompok & Eksperimen & Kontrol & Hasil \\
\hline$\overline{X_{i}}$ & 74.94 & 69.58 & \\
\cline { 1 - 3 }$s_{i}$ & 7.753 & 6.874 & \\
hitung & $\geq t_{\text {tabel }}$ \\
\hline
\end{tabular}




\begin{tabular}{|c|c|}
\hline$n_{i}$ & 36 \\
\hline$S^{2}$ & 53,968 \\
\hline$S$ & 7,346 \\
\hline $\mathrm{t}_{\text {hitung }}$ & 3,032 \\
\hline $\mathrm{t}_{\text {tabel }}$ & 1,996 \\
\hline
\end{tabular}

Tabel 4 menunjukkan nilai t hitung lebih dari sama dengan nilai t table berarti motivasi belajar matematika siswa kelas yang mengkuti pembelajaran dengan metode hypnoteaching lebih tinggi daripada motivasi belajar matematika siswa kelas yang mengikuti pembelajaran konvensional. Temuan yang didapatkan menunjukan keefektifan penggunaan metode hypnoteaching dalam pembelajaran daripada pembelajaran dengan metode konvensional.

Perbedaan yang terjadi antara kelompok eksperimen dan kelompok kontrol dari segi keaktifan siswa dalam mengakses dan menjawab soal latihan yang ada pada platform schoology. Pada saat jam pembelajaran dimulai kelompok eksperimen lebih antusias terlihat dari waktu pengerjaan latihan soal di schoology. Soal latihan yang diberikan terlihat pada Gambar 2 dan Gambar 3 dimana siswa pada kelompok eksperimen mendapatkan nilai yang lebih tinggi dibandingkan dengan kelompok kontrol.

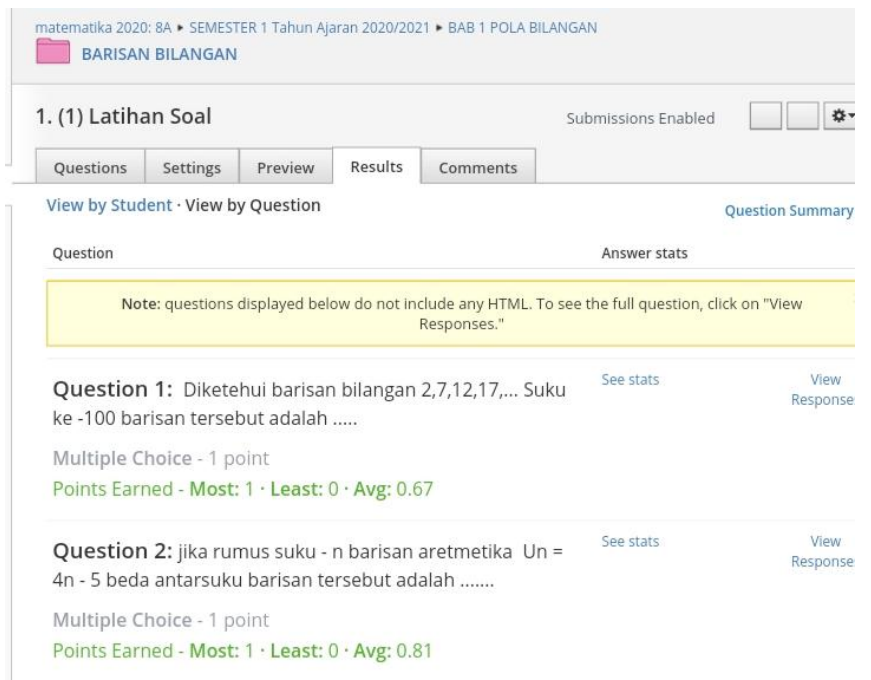

Gambar 2. Hasil Latihan Soal Kelompok Eksperimen

Kelompok eksperimen memiliki rata-rata menjawab soal nomor 1 dengan benar sebesar $67 \%$. Kemudian rata-rata benar untuk soal nomor 2 yaitu $81 \%$. Kemudian untuk kelompok kontrol terdapat pada Gambar 3. 


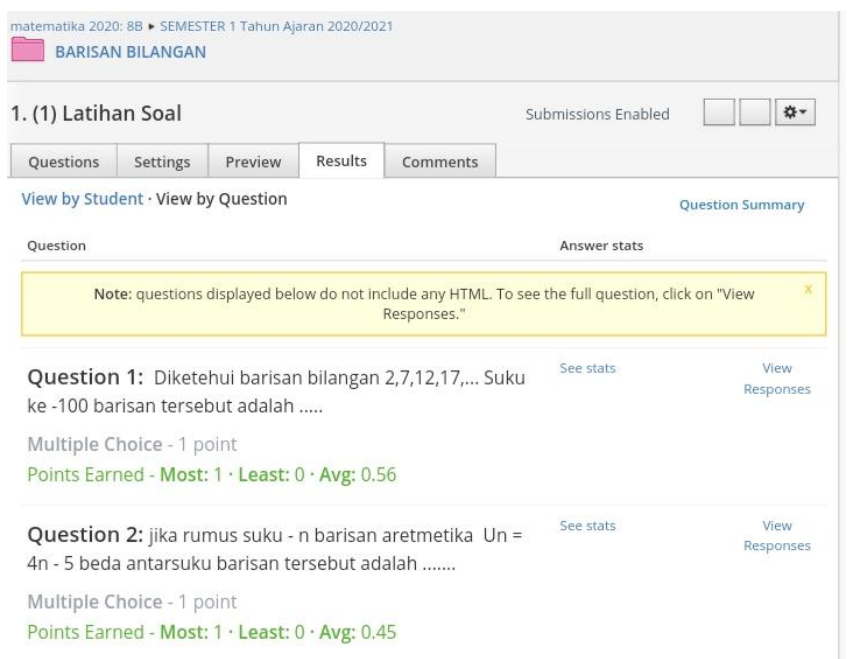

Gambar 3. Hasil Latihan Soal Kelompok Kontrol

Pada Gambar 3 menunjukkan hasil dari latihan soal kelompok kontrol dengan ratarata benar menjawab soal nomor 1 yaitu $56 \%$ sedangkan untuk soal nomor 2 yaitu $45 \%$. Hal tersebut tidak menutup kemungkinan karena kelompok eksperimen menerapkan pembelajaran menggunakan metode hypnoteaching yang dapat menciptakan pola pikir siswa menjadi senang untuk belajar. Selain itu pembelajaran yang diakses secara online memudahkan siswa untuk mencermati kembali terkait sumber belajar yang disediakan oleh guru. Sumber belajar siswa selain buku yang telah disediakan terdapat pula dari internet terkesan lebih mudah dan menyenangkan (Suryawan \& Permana, 2020). Hal tersebut memantapkan kelompok eksperimen terkait pembelajaran dengan metode hypnoteaching yang dapat diakses dimana dan kapan saja melalui platform schoology .

Dari hasil pengisian angket motivasi belajar matematika terlihat rata-rata skor motivasi siswa kelas eksperimen lebih tinggi. Metode hypnoteaching menekankan penggunaan secara optimal pikiran sadar dan bawah sadar siswa (Yan, 2010). Selain itu, manfaat yang diberikan diantaranya proses pembelajaran menjadi menyenangkan, perhatian siswa tertuju pada pembelajaran, lebih meningkatkan semangat dan mengatasi rasa malas dan siswa lebih bisa mengendalikan ego maupun rasa bosannya (Kusuma, 2019). Manfaat tersebut tidak terlepas dari langkah- langkah yang diterapkan.

Kelebihan langkah-langkah hypnoteaching yang bermula dari niat dan motivasi, dilanjutkan pacing, leading, penggunaan kata-kata positif, pujian dan diakhiri dengan modeling. Mempersepsikan pengajar sebagai guru yang sadar dengan memberikan motivasi dan niat positif dalam dirinya untuk mengajar seperti saya guru rajin, saya disukai siswa maupun saya guru yang berkeinginan kuat untuk terus belajar setiap waktu (Salami, 2017). Penerapan selftalk pada diri seorang pengajar membuat timbulnya keikhlasan diri 
untuk menjalankan tugasnya sepenuh hati, ceria dan persepsi positif yang diterimanya melalui bahasa tubuh dan lisannya dalam pembelajaran. Hal tersebut terlihat dari persiapan materi yang akan diajarkan pada platform schoology.

Terciptannya proses pembelajaran yang beragam dengan mengajak siswa untuk berimajinasi dan berpikir secara kreatif. Sejalan dengan pendapat HM Anwar (2017) terkait hypnoteaching yang menekankan komunikasi siswa melalui alam bawah sadar mereka dan berbagai cara yang imajinatif maupun sugesti. Imajinatif diartikan sebagai proses membayangkan sesuatu dilanjutkan dengan bertindak. Beragamnya proses pembelajaran disuguhkan dari cerita singkat permasalahan video 2D pada Gambar 4.

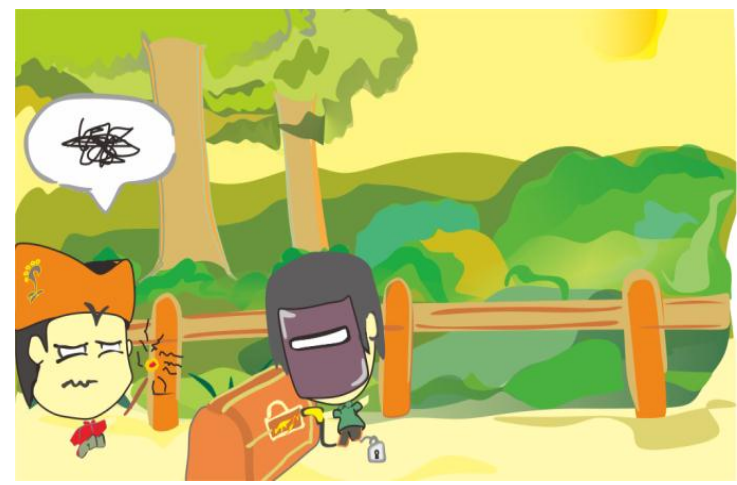

Gambar 4. Permasalahan Video Animasi 2D

Dari pengamatan video yang dilakukan, siswa akan mulai berimajinasi dan muncul keinginan mencoba permasalahan tersebut dengan penyelesaian yang berbeda-beda. Amalia dkk (2019) menjelaskan pemberian cerita-cerita yang menginspirasi maupun mensugesti tentang hal yang berkaitan dengan matematika seperti sejarah dan perkembangan matematika akan memberikan antusias lebih pada siswa. Permasalahan terkait kehidupan sehari-hari diberikan yang menunjang pola pikir siswa akan pentingnya matematika dalam kehidupan sekitar (Fatimah et al., 2019). Diberikan hak untuk memecahkan persoalan yang telah disediakan menyebabkan timbulnya kreativitas siswa. Upaya yang dilakukan siswa dalam menghubungkan gagasan atau pengamatan tersebut yang menjadikan kreativitas muncul yang kemudian pola pikir mereka akan berkembang (Ndiung, Sennen, Helmon, \& Jediut, 2020). Ada kegiatan bernyayi disertai gerakan maupun senam otak. Kesiapan menerima materi akibat rasa nyaman yang muncul dari langkah pacing membuat proses pembelajaran semakin termotivasi. Miftakhurozaq (2018) menjelaskan dengan rasa nyaman yang telah diberikan membuat pesan dari orang lain diterima dan dipahami secara baik sehingga muncul motivasi untuk belajar.

Mudahnya penguasaan materi yang dirasakan siswa merupakan hal yang diperlihatkan pada langkah leading. Berkat langkah pacing yang sebelumnya telah 
dilakukan yang menjadikan suasana lingkungan belajar menjadi nyaman. Rasa nyaman yang dirasakan selama kegiatan pembelajaran sangat mempengaruhi aktifnya siswa (Eccles \& Wigfield, 2002). Pusat perhatian siswa tertuju kepada materi yang telah disediakan dikarenakan permasalahan tokoh maupun pengadaan senam otak pada tahap pacing membuat konsentrasi siswa menjadi tajam. Gerakan senam otak terlihat pada Gambar 5 dilakukan dengan beberapa variasi tangan maupun gerakan anggota tubuh yang mudah dipraktikan. Hal ini mempermudah kegiatan siswa, mengurangi stress maupun menciptakan pembelajaran yang menyenangkan (Agustina \& Wahyuni, 2019).

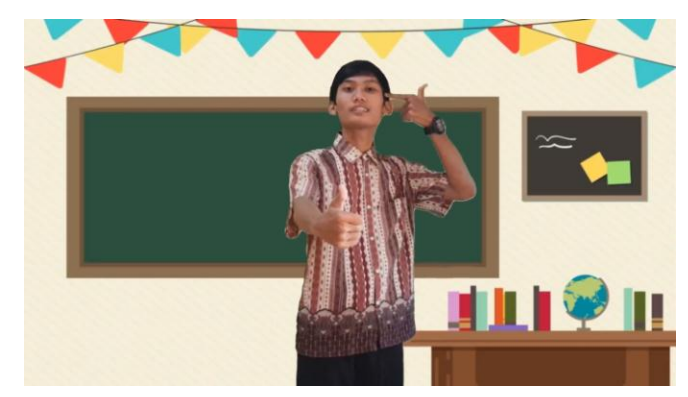

Gambar 5. Gerakan Senam Otak dalam Pembelajaran

Langkah pendukung dalam proses pembelajaran yaitu penggunaan kata-kata positif seperti "kamu pintar", "kamu pasti bisa melakukannya"," saya yakin kamu sanggup melakukannya" yang memberikan kenyakinan siswa terhadap dirinya sendiri untuk terus aktif dan tumbuh jiwa untuk belajar. Suntikan energi berupa kata- kata positif siswa berpengaruh terhadap siswa untuk giat belajar tanpa menyuruhnya dengan kasar yang hanya akan menyebabkan siswa jengkel dan niat untuk belajar semakin berkurang (Bali \& Masulah, 2019). Hal tersebut menjadikan terleburnya kesulitan siswa dalam memahami dan membuat perhatian terpusat ke materi.

Hasil dan pekerjaan yang telah dilakukan perlu adanya penghargaan atas kerja kerasnya. Langkah berikutnya yaitu pujian yang merupakan hal istimewa bagi siswa sehingga perlu pemberian pujian yang tepat. Tepatnya pemberian pujian memberikan gairah belajar, suasana hati yang menyenangkan dan akhirnya harga diri siswa bangkit (Sadirman, 2011). Pemberian pujian dilakukan dengan cara berkomentar pada hasil perkerjaan yang telah siswa kerjakan.

Hasil penelitian ini sejalan dengan Kasmaja (2016), yang menyatakan bahwa terdapat peningkatan motivasi belajar matematika siswa pada setiap indikator dimensi intrinsik maupun ekstrinsik seperti motivasi menghindari hukuman dari guru dimana siswa merasa memiliki tanggung jawab untuk mengerjakan tugas. Sejalan dengan penelitian ini 
Hasbullah \& Rahmawati (2015), menyatakan bahwa metode hypnoteaching mampu meningkatkan motivasi belajar matematika mahasiswa dan relevan diberikan pada setiap jenjang pendidikan dan materi pembelajaran.

\section{KESIMPULAN}

Berdasarkan rata-rata skor motivasi siswa dan gambaran deskriptif yang dilakukan, diketahui bahwa keefektifan metode hypnoteaching dalam memotivasi belajar matematika siswa memiliki pengaruh yang positif dibandingkan pembelajaran konvensional. Terbukti dari hasil uji hipotesis yang telah dilakukan terhadap skor post-test motivasi belajar matematika siswa yang menunjukkan adanya perbedaan yang signifikan. Motivasi belajar matematika siswa dengan metode hypnoteaching lebih tinggi daripada motivasi belajar matematika siswa dengan metode pembelajaran konvensional. Dengan demikian metode hypnoteaching efektif diterapkan pada pemebalajaran matematika.

\section{REFERENSI}

Agustina, W., \& Wahyuni, S. (2019). Hasil Belajar Siswa Berdasarkan Intensitas Kegiatan Brain Gym pada Pembelajaran Matematika. JP2M (Jurnal Pendidikan Dan Pembelajaran Matematika), 4(2), 93. https://doi.org/10.29100/jp2m.v4i2.960

Amalia, R., Zaki, M., \& Sofiyan, S. (2019). Pendampingan Anak-anak Usia Sekolah dalam Rangka Implementasi Hypnoteaching untuk Meningkatkan Motivasi Belajar Matematika di Kuala Langsa. Jurnal Pengabdian Masyarakat MIPA Dan Pendidikan MIPA, 3(2), 80-88. https://doi.org/10.21831/jpmmp.v3i2.23679

Bali, M. M. E. I., \& Masulah, I. (2019). Hypnoteaching: Solusi Siswa Learning Disorder. At-Turats, 13(1), 89-103. https://doi.org/10.24260/at-turats.v13i1.1188

Budiman, H., \& Rosmiati, M. (2020). Penerapan Teori Belajar Van Hiele Berbantuan Geogebra untuk Meningkatkan Kemampuan Penalaran Matematis Siswa. Prisma, 9(1), 47. https://doi.org/10.35194/jp.v9i1.845

Dewi, P. S. (2018). Efektivitas Pendekatan Open Ended Ditinjau dari Kemampuan Pemecahan Masalah Matematis. PRISMA, 7(1), 11-19. https://doi.org/https://doi.org/10.35194/jp.v7i1.340

Diantari, P., Wiarta, W., \& Negara, G. A. O. (2014). Pengaruh Model Pembelajaran Problem Based Learning Berbasis Hypnoteaching Terhadap Hasil Belajar Matematika Siswa. Jurnal Mimbar PGSD Universitas Pendidikan Ganesha, 2(1), 1-10. https://doi.org/http://dx.doi.org/10.23887/jjpgsd.v2i1.3103

Eccles, J. S., \& Wigfield, A. (2002). Motivational Beliefs, Values, and Goals. Annual Review of Psychology, 53(1), 109-132. https://doi.org/10.1146/annurev.psych.53.100901.135153

Fatimah, R. N., dkk. (2019). Teknik Probing-Promting Scaffolding pada Pemecahan Masalah Matematis. Prisma, 8(2), 146-159.

Hasbullah, H., \& Rahmawati, E. Y. (2015). Pengaruh Penerapan Metode Hypnoteaching Terhadap Motivasi Belajar Mahasiswa Universitas Indraprasta PGRI. Formatif: Jurnal Ilmiah Pendidikan MIPA, 5(1), 83-90. https://doi.org/10.30998/formatif.v5i1.163

Hasibuan, E. K. (2018). Analisis Kesulitan Belajar Matematika Siswa Pada Pokok Bahasan 
Bangun Ruang Sisi Datar Di Smp Negeri 12 Bandung. AXIOM : Jurnal Pendidikan Dan Matematika, 7(1), 18-30. https://doi.org/10.30821/axiom.v7i1.1766

Hastjarjo, T. D. (2019). Rancangan Eksperimen-Kuasi. Buletin Psikologi, 27(2), 187-203. https://doi.org/10.22146/buletinpsikologi.38619

Hewi, L., \& Shaleh, M. (2020). Refleksi Hasil PISA (The Programme For International Student Assesment): Upaya Perbaikan Bertumpu Pada Pendidikan Anak Usia Dini ). 4(1), 30-41.

HM Anwar, M. (2017). Menciptakan Pembelajaran Efektif Melalui Hypnoteaching. Ekspose: Jurnal Penelitian Hukum Dan Pendidikan, 16(2), 469-480. https://doi.org/10.30863/ekspose.v16i2.106

Inayah, S., Septian, A., \& Suwarman, R. F. (2020). Student Procedural Fluency in Numerical Method Subjects. Desimal: Jurnal Matematika, 3(1), 53-64. https://doi.org/10.24042/djm.v3i1.5316

Kasmaja, H. (2016). Efektivitas Implementasi Metode Hypnoteaching untuk Meningkatkan Motivasi dan Hasil Belajar Matematika Pada Siswa SMP Negeri. Journal of Educational Science and Technology (EST), 2(1), 33-45. https://doi.org/10.26858/est.v2i1.1889

Kusuma, D. A. (2019). Penerapan Ethnomathematics dan Hypnoteaching pada Mata Kuliah Matematika Kimia. JNPM (Jurnal Nasional Pendidikan Matematika), 3(2), 165-176. https://doi.org/10.33603/jnpm.v3i2.2279

Menteri Pendidikan dan Kebudayaan Republik Indonesia. (2020). Surat Edaran Nomor 4 Tahun 2020 Tentang Pelaksanaan Kebijakan Pendidikan Dalam Masa Darurat Penyebaran Coronavirus Disease (COVID-19) (p. 300). p. 300.

Mertasari, N. M. S. (2003). Pengaruh Model Tes Terhadap Motivasi Belajar Matematika dengan Mempertimbangkan Tingkat Kesukaran Tes. (tidak diterbitkan).Institut Keguruan dan Ilmu Pendidikan Negeri Singaraja.

Miftakhurozaq, M. (2018). Implementasi Metode Hypnoteaching dalam Pembelajaran PAI. Ta'allum: Jurnal Pendidikan Islam, 6(1), 83-104. https://doi.org/10.21274/taalum.2018.6.1.83-104

Ndiung, S., Sennen, E., Helmon, A., \& Jediut, M. (2020). Efektivitas Model Pembelajaran Treffinger dalam Menumbuhkan Keterampilan Berpikir Kreatif Peserta Didik Sekolah Dasar. PRISMA, 9(2), 167-178.

Parwati, N. N., Suryawan, I. P. P., \& Apsari, R. A. (2018). Belajar dan Pembelajaran (1st ed.). Singaraja: PT RAJAGRAFINDO PERSADA.

Purwanto, A., Pramono, R., Asbari, M., Santoso, P. B., Wijayanti, L. M., Choi, C. H., \& Putri, R. S. (2020). Studi Eksploratif Dampak Pandemi COVID-19 Terhadap Proses Pembelajaran Online di Sekolah Dasar. EduPsyCouns: Journal of Education, Psychology and Counseling, 2(1), 1-12.

Qomario, Q. (2018). Pengaruh Hypnoteaching Dalam Contextual Teaching and Learning Terhadap Kemampuan Komunikasi Matematis. Refleksi Edukatika: Jurnal Ilmiah Kependidikan, 9(1), 46-55. https://doi.org/10.24176/re.v9i1.2808

Sadirman, A. M. (2011). Interaksi \& Motivasi Belajar Mengajar. Jakarta: Jakarta: PT. Raja Grafindo Persada.

Safitri, D. N., \& Purnamasari, N. I. (2017). Efektivitas Pembelajaran Matematika Dengan. Journal Pendidikan Matematika, 3(1), 1-8. https://doi.org/https://doi.org/10.26638/je.264.2064

Salami. (2017). Hypnotic Teacher Dan Hypnoteaching. 3(1), 34-44.

Septian, A., Darhim, \& Prabawanto, S. (2020a). Geogebra in integral areas to improve mathematical representation ability Geogebra in integral areas to improve mathematical representation ability. Journal of Physics: Conference Series, 1613(1), 
012035. https://doi.org/10.1088/1742-6596/1613/1/012035

Septian, A., Darhim, \& Prabawanto, S. (2020b). Mathematical representation ability through geogebra-assisted project- based learning models. Journal of Physics: Conference Series, 1657(1), 012019. https://doi.org/10.1088/17426596/1657/1/012019

Suryawan, I. P. P., \& Permana, D. (2020). Media Pembelajaran Online Berbasis Geogebra sebagai Upaya Meningkatkan Pemahaman Konsep Matematika. Prisma, 9(1), 108. https://doi.org/10.35194/jp.v9i1.929

Suwarman, R. F. (2018). Analisis Tingkat Kemampuan Pemahaman Konsep. Jurnal Prisma, VII(2), 227-237.

Trisnawati, F. (2020). Gambaran Perilaku Burnout di SMP Negeri 2 Pedamaran. JUANG: Jurnal Wahana Konseling, 3(1), 53-62. https://doi.org/http://dx.doi.org/10.31851/juang.v3i1.4893

Utami, Y. P., \& Cahyono, D. A. D. (2020). Study at Home: Analisis Kesulitan Belajar Matematika pada Proses Pembelajaran. Jurnal Ilmiah Matematika Realistik, 1(1), 2026. https://doi.org/10.33365/ji-mr.v1i1.252

Yan, N. (2010). The Secret of Stage Hypnosis Revealed. Jakarta: Jakarta: Gramedia.

Yustisia, N. (2012). Hypnoteaching: Seni Mengeksplorasi Otak Siswa. Yogyakarta: Yogyakarta: Ar-Ruzz Media. 